\title{
What the Intensivist Needs to Know About Hematopoietic Stem Cell Transplantation?
}

\author{
Brion V. Randolph and Stefan O. Ciurea
}

\section{Contents}

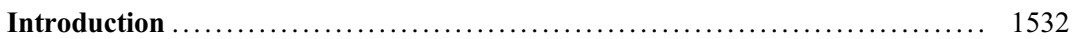

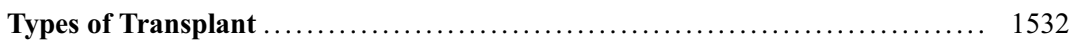

Overview of the Transplant Process ............................... 1533

Complications After Autologous HSCT ............................ 1535

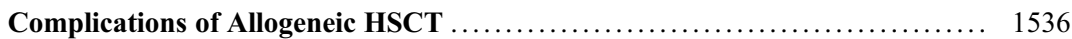

Pre-engraftment Complications .................................... 1537

Early Post-engraftment Complications ................................ 1537

Late Post-engraftment Complications .............................. 1540

End of Life Issues in HSCT Patients Admitted to the ICU ................. 1541

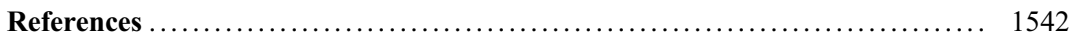

\begin{abstract}
Hematopoietic stem cell transplantation (HSCT) is a potential curative therapy for some patients with hematologic conditions. There are two main types of HSCT. This includes autologous HSCT, for which the stem cells are obtained from the patient, and allogeneic HSCT, for which the stem cells are obtained from a related or unrelated donor. The most common indications for
\end{abstract}

B. V. Randolph

Hematology/Oncology, Medical University of South

Carolina, Charleston, SC, USA

e-mail: randolbr@musc.edu

S. O. Ciurea $(\bowtie)$

The University of Texas MD Anderson Cancer Center, Houston, TX, USA

e-mail: sciurea@mdanderson.org

(C) Springer Nature Switzerland AG 2020

J. L. Nates, K. J. Price (eds.), Oncologic Critical Care, https://doi.org/10.1007/978-3-319-74588-6_99 autologous stem cell transplant are multiple myeloma and relapsed/refractory lymphoma, whereas leukemia and bone marrow failure syndromes remain the most common indications for allogeneic stem cell transplant. This chapter will review the different types, indications, processes, and main complications of HSCT. This chapter will also discuss end-of-life issues that patients and providers face when transplant patients are admitted for the intensive care unit.

\section{Keywords}

Stem cell transplant - Bone marrow transplant . Transplant · Autologous · Allogeneic · Graftversus-host disease (GVHD) - Veno-occlusive disease (VOD) - Sinusoidal obstruction syndrome (SOS) $\cdot$ Idiopathic pulmonary syndrome 


\section{Introduction}

Hematopoietic stem cell transplantation (HSCT) remains one of the only potentially curative therapies for some patients with both benign and malignant blood disorders. The concept of HSCT was first recognized in the 1950s in animal models as a means of marrow recovery following lethal doses of total body irradiation [14]. This concept was then reported by Thomas et al. in 1957 in human patients with leukemia [43, 72-74]. Today, HSCT has broad indications which have expanded to include both benign and malignant conditions.

\section{Types of Transplant}

HSCT can be categorized into two main types, autologous and allogeneic. A summary of the key differences in these types of transplants is provided in Fig. 1.

Autologous HSCT involves the use of the patient's own stem cells to rescue the bone marrow following the administration of high-dose (myeloablative) chemotherapy. The aim of this type of transplant is to eradicate residual cancer cells that have demonstrated intermediate resistance to standard doses of chemotherapy. Cytotoxicity is the main benefit of this type of transplant because there is no immune attack against the cancer cells. Relapsed/aggressive

lymphoma and multiple myeloma remain the primary indications for autologous HSCT [18]. However, the use of this type of transplant has also extended to autoimmune diseases. A comprehensive list of the potential indications for autologous stem cell transplant is provided in Table 1.

Allogeneic HSCT involves the infusion of stem cells from a related or unrelated donor resulting in two mechanisms for fighting the cancer. The mechanisms of disease eradication include both the cytotoxic effects of the chemotherapy and the donor's immune system to attack residual cancer cells (graft-versus-tumor effect). In addition to eliminating residual cancer cells, the chemotherapy administered in an allogeneic stem cell transplant is used to also suppress the recipient's immune system to prevent rejection of the donor cells (graft). Patients typically receive additional immunosuppressive therapy with calcineurin inhibitors (i.e., tacrolimus, sirolimus), mycophenolate mofetil $\left(\right.$ CellCept $\left.{ }^{\circledR}\right)$, and/or other drugs (methotrexate, antithymocyte globulin) to both prevent rejection of the graft and protect normal recipient/host cells from being attacked by the graft which is known as graft-versus-host disease (GVHD). Acute leukemia and myelodysplastic syndromes remain the most common indications for allogeneic HSCT [18]. However, advanced chronic leukemias, lymphomas, and hemoglobinopathies are also treated with this type of transplantation. A more comprehensive list of indications for allogeneic HSCT is provided in Table 2.

Fig. 1 Summary of the types of HSCT

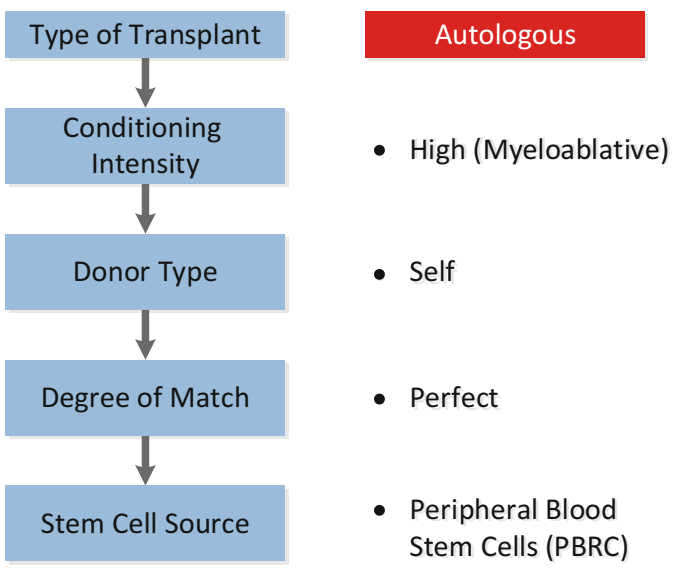

\author{
Allogeneic \\ - High (Myeloablative) \\ - Reduced Intensity \\ - Related \\ - Unrelated \\ - Matched \\ - Mismatched \\ - Highly Mismatched \\ - PBSC \\ - Bone Marrow \\ - Umbilical Cord Blood
}


Table 1 Diseases commonly treated with autologous HSCT [15]

\begin{tabular}{l}
\hline Hematological malignancies \\
\hline Multiple myeloma \\
\hline Light chain amyloidosis \\
\hline Non-Hodgkin's lymphoma \\
\hline Hodgkin's lymphoma \\
\hline Acute myeloid leukemia \\
\hline Solid tumors \\
\hline Neuroblastoma \\
\hline Germ cell tumors \\
\hline Other diseases \\
\hline Autoimmune disorders (i.e., scleroderma)
\end{tabular}

Table 2 Diseases commonly treated with allogeneic HSCT [15]

\begin{tabular}{l}
\hline Hematologic malignancies \\
\hline Acute myeloid leukemia \\
\hline Acute lymphoblastic leukemia \\
\hline Chronic myeloid leukemia \\
\hline Myelodysplastic syndromes \\
\hline Myeloproliferative disorders \\
\hline Non-Hodgkin's lymphoma \\
\hline Hodgkin's lymphoma \\
\hline Chronic lymphocytic leukemia \\
\hline Multiple myeloma \\
\hline Other diseases \\
\hline Aplastic anemia \\
\hline Paroxysmal nocturnal hemoglobinuria \\
\hline Fanconi's anemia \\
\hline Blackfan-Diamond anemia \\
\hline Thalassemia major \\
\hline Sickle cell anemia \\
\hline Severe combined immunodeficiency \\
\hline Wiskott-Aldrich syndrome \\
\hline Inborn errors of metabolism (i.e., Gaucher's disease) \\
\hline
\end{tabular}

Allogeneic HSCT is one of the first examples of immunotherapy in oncology because of its ability to use the donors immune system as a means of fighting cancer. In addition to changing the hematopoietic progenitor cells, a change in recipient's with donor's immune system occurs. Cellular therapy builds on the foundation of collection and infusion of hematopoietic cells used for anti-cancer therapy. The therapeutic immunologic effect of the graft was first described in the field of allogeneic stem cell transplant in the 1950s as a graft-versus-leukemia effect (GVL). The GVL effect is identified following observations of a decrease in relapse rate in leukemia patients who developed graft-versus-host disease (GVHD) after allogeneic stem cell transplant and further supported by the increased relapse rate seen after syngeneic transplants and transplants using T-cell-depleted grafts [80]. The GVL effect, caused mostly by donor lymphocytes, prompted to the use of donor lymphocyte infusions as one of the earlier forms of cellular therapy subsequently modified genetically to be antigen specific [i.e., chimeric antigen receptor (CAR)-modified T-cells], to target different types of leukemias, lymphoma, and other malignances.

\section{Overview of the Transplant Process}

Regardless of the type of transplant, patients receiving HSCT undergo a similar process that is centered around the day of stem cell infusion, which is known as "Day 0." The days prior to transplant are designated with a minus sign. Thus, Day -10 would represent 10 days prior to the planned infusion of the stem cells. The days after infusion of the stem cells are designated with a plus sign such that Day +30 would indicate that the patient is 30 days post infusion of stem cells. The transplant process starts with a referral or consultation by the stem cell transplant team, which initiates the process for insurance/financial clearance, assessment of comorbidities/organ function, and evaluation of the functional status of the patient and decision on what type of transplant is indicated. This process typically takes 2-3 months and will occur concomitantly with the primary or salvage therapy for management of the disease. Once the patient is both clinically suitable and financially approved, arrangements are made to collect the stem cells either via apheresis in the case of both autologous and allogeneic HSCT or bone marrow harvest in select cases of allogeneic stem cell transplantation.

The actual transplant process begins with the patient receiving conditioning chemotherapy, which is known also as the preparative regimen. In general, the pretransplant conditioning 
Autologous HSCT

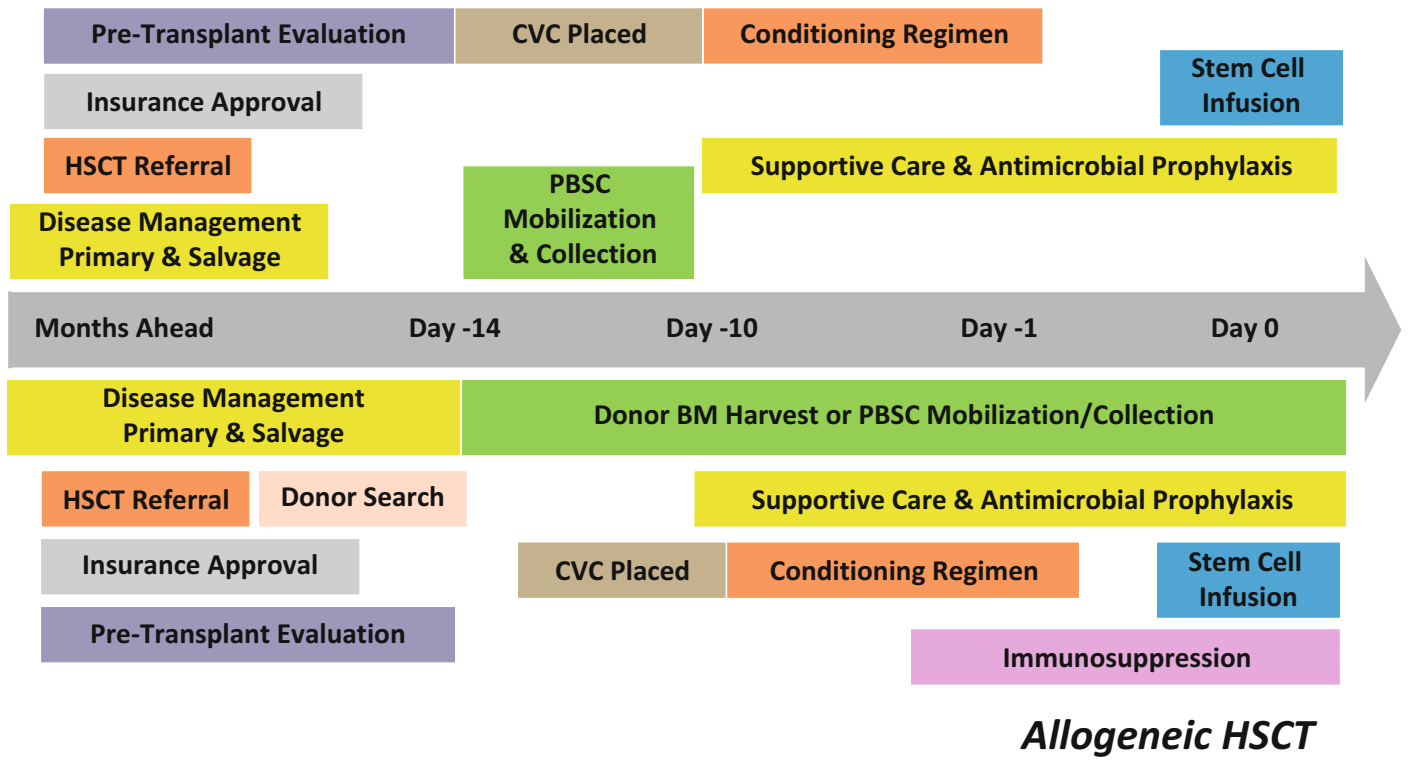

Fig. 2 Summary of pre-HSCT process

regimens consist of a combination of chemotherapy drugs with or without radiation with the goal to immunosuppress the recipient and eliminate as much tumor as possible. These regimens are classified as myeloablative, non-myeloablative, or reduced intensity. Myeloablative regimens are defined by their ability to eradicate the recipient's bone marrow with associated profound cytopenia and lack of autologous hematopoietic recovery. Non-myeloablative (NMA) regimens typically cause minimal cytopenia and relying primarily on a GVL effect for disease eradication. Reduced-intensity protocols are an intermediate intensity group of regimens, a middle of the road between ablative and NMA conditioning [5]. The preferred preparative regimen is dependent upon a combination of disease- and patient-related factors. The conditioning regimen is typically administered between Day -10 and Day -2 with a day of "rest" prior to the stem cell infusion to allow for clearance of the cytotoxic chemotherapy, thereby avoiding potential damage to the infused stem cells. On "Day 0," the stem cells are infused into the patient via a central venous catheter.

In the case of allogeneic stem cell transplant, patients also receive immunosuppressant therapy that is typically started a few days prior to the infusion of stem cells and often continued for up to 6 months posttransplant. All patients receive a combination of antimicrobial, antifungal, and antiviral prophylactic therapy. The pretransplant process ends with the infusion of the stem cells and is summarized in Fig. 2.

The next phase of transplant is commonly known as the recovery period and begins after the infusion of the stem cells. For patients who undergo autologous HSCT, this period will typically last about 6 months culminating with the administration of vaccines. For allogeneic HSCT, this period may last longer dependent upon whether the patient develops graft-versushost disease or other transplant-related complications discussed later in this chapter. In both autologous and allogeneic HSCT, the recovery period is associated with approximately 2-4 weeks of myelosuppression from the conditioning chemotherapy regimen. It is during this time that the donor cells migrate to the bone marrow and begin to produce new blood cells. Patients may require transfusion of blood products during this time and are at greatest risk for bacterial, fungal, and certain viral infections due to low neutrophil 


\section{Autologous HSCT}

Disease recurrence monitoring \& management

Supportive Care \& Antimicrobial Prophylaxis

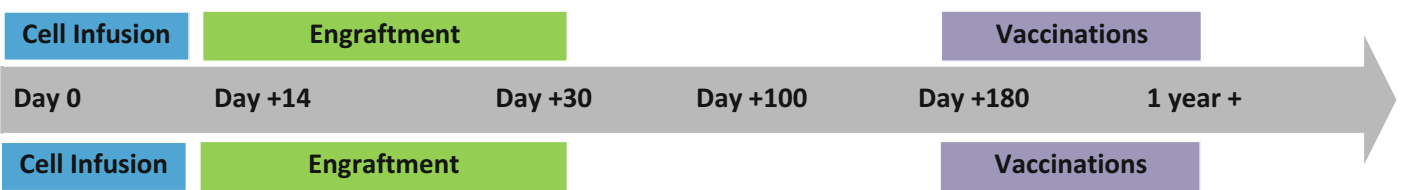

Supportive Care \& Antimicrobial Prophylaxis (stop once off immunosuppression \& steroids)

Immunosuppression (taper at 6 mo if no GVHD)

Acute GVHD

Chronic GVHD

\section{Allogeneic HSCT}

Fig. 3 Summary of the recovery period

counts and potential mucosal damage from mucositis. The extent of immunosuppression during this time is determined by the intensity of the chemotherapy regimen. Immunosuppression may be more prolonged in allogeneic HSCT due to the use of steroids and other immunosuppressant medications for the treatment of GVHD. The post-HSCT process is summarized in Fig. 3.

\section{Complications After Autologous HSCT}

With appropriate patient selection, autologous HSCT is generally considered a well-tolerated procedure with an estimated transplant-related mortality (TRM) of less than 3\% within the first 100 days posttransplant [35]. In fact, the most common cause of death after autologous HSCT remains disease relapse accounting for up to $69 \%$ of such deaths [35].

The use of myeloablative chemotherapy for autologous HSCT results in profound pancytopenia, which puts the patient at risk for bacterial, fungal, and viral infections. Patients tend to be at greatest risk for bacterial infections in the early posttransplant period (prior to neutrophil engraftment), although other infections like viral or fungal can also occur during this time period. The estimated rate of admission to the ICU after autologous HSCT remains low with one study of 1013 patients showing a rate of only $3.3 \%$ [11]. The overall mortality of all patients in the cohort was $1 \%$. However, this increased to $38 \%$ for those patients admitted to the ICU [11]. The most common reasons for ICU admission were systemic inflammatory response/sepsis $(32 \%)$, respiratory failure $(29 \%)$, and cardiovascular failure $(26 \%)$ [11]. The majority of patients had an underlying diagnosis of multiple myeloma or AL amyloidosis $(85 \%)$ with the greatest disease-specific ICU mortality associated with AL amyloidosis patients $(54.5 \%)$ [11]. The study also found a correlation between mortality and both the Sequential Organ Failure Assessment (SOFA) score and Acute Physiology and Chronic Health Evaluation (APACHE II) score in the first $24 \mathrm{~h}$ of ICU admission suggesting possible tools to assist in clinical decision-making regarding the continuation of intensive care delivered after $24 \mathrm{~h}$ of ICU admission [77].

In addition to infectious complications, many of the patients undergoing autologous HSCT will develop gastrointestinal complications from the preparative chemotherapy regimen. The two most common preparative regimens for autologous HSCT are single-agent melphalan (primarily used for plasma cell disorders) and the combination of BCNU/carmustine, etoposide, Ara-C/ cytarabine, and melphalan (BEAM) (primarily used for lymphomas). These regimens are 
considered myeloablative and may result in varying degrees of damage to the GI tract mucosa with mucositis, nausea/vomiting, diarrhea, altered taste, and a period of anorexia. Neutropenia lasts for 1-2 weeks and may be associated with neutropenic fever and bacteremia, requiring broad antimicrobial coverage, occasional sepsis, and need for ICU care. In addition, older patients may be more prone to cardiac toxicity and development of atrial fibrillation, especially if there is a history of atrial fibrillation, and renal insufficiency or volume overload. However, most of these effects tend to resolve within a short period of time after neutrophil engraftment has occurred.

Late effects of autologous HSCT are relatively uncommon with second primary malignancies, obstructive/restrictive lung impairment, and viral infections being the most reported late complications. A study of 1617 lymphoma survivors found a cumulative incidence of secondary neoplasms of $6.5 \%$ [46]. The most common type of neoplasm was a hematologic malignancy $(43.8 \%)$, which included myelodysplastic syndrome (MDS), myeloproliferative disorder (MPN), and acute myelogenous leukemia (AML) [46]. A study of lymphoma patients in Japan reported an incidence of MDS and AML of 1.8\% for long-term survivors after autologous HSCT. However, there was increased concern for patients with multiple myeloma who were found in trials of maintenance therapy after autologous HSCT to have an incidence of secondary malignancies of $8-14 \%$ when receiving maintenance versus $4-5 \%$ without maintenance therapy $[3,31,44]$.

While pulmonary complications of autologous HSCT seem to be rare, Stenehjem et al. have reported an incidence of $11.5 \%$ and $5.8 \%$ for obstructive and restrictive lung impairment, respectively, in 226 lymphoma survivors after autologous HSCT [69]. Current smoking and cumulative doxorubicin dose of 400-775 mg/m were risk factors for obstructive disease, while chest radiation greater than 13-66 Gy seemed to increase the risk for restrictive lung disease and pulmonary complications [69].

Lastly, patients receiving an autologous HSCT remain at risk for viral and atypical infections (i.e., varicella-zoster virus and Pneumocystis jirovecii) for several months post-engraftment while awaiting recovery of the lymphocyte population, which usually reaches a safer level by 100 days posttransplant $[51,75]$. It is for this reason that many patients will remain on prophylactic medications like acyclovir or valacyclovir, Bactrim, Mepron, or pentamidine for 3-6 months after transplant. Patients are also recommended to undergo repeat vaccination for measles, mumps, rubella, tetanus, diphtheria, Haemophilus influenzae, polio, and influenza, which typically begins at 6 months after the transplant [75].

\section{Complications of Allogeneic HSCT}

Complications of allogeneic HSCT are generally secondary to chemotherapy side effects, prolonged immunosuppression, or immune-related effects of the donor cells. Unlike with autologous HSCT, there is also a higher risk for graft failure/ rejection and higher non-relapse mortality (NRM). Overall NRM after allogeneic HSCT has improved significantly over time due to better HLA typing, improvements in patient selection, and supportive care [27, 28, 32].

The use of antimicrobial prophylaxis, growth factors, preemptive antiviral therapy, and peripheral blood stem cells have contributed to better transplant outcomes. Furthermore, the use of predictive tools in the upfront selection process seems to be beneficial with many US centers incorporating a standardized HSCT Comorbidity Index (HCT-CI) to help in the selection of patients for transplant. The HCT-CI utilizes weighted scores for the presence of a variety of comorbidities to help predict non-relapse mortality. The comorbidities include active gastrointestinal disease, coagulopathy, endocrine disease, hypertension, arrhythmia, inflammatory bowel disease, diabetes, cerebrovascular disease, rheumatologic disease, peptic ulcer, asthma, obesity, infection, psychiatric disturbances, heart valve disease, and prior solid tumor. The HCT-CI yields a calculated score between 0 and 26 allowing for patients to be classified into one of three groups: low risk (score of 0 ), intermediate risk (score of $1-2$ ), or high risk (score of 3 or higher). Patients 
with low, intermediate, and high risk have an estimated 2-year non-relapse mortality of $14 \%$, $19-22 \%$, and approximately $40 \%$, respectively [67]. HCT-CI has also been shown to be a valid tool in predicting outcomes for patients receiving allogeneic HSCT who subsequently require critical care. In a single institution review of 377 patients admitted to the intensive care unit (ICU) within 100 days of allogeneic HSCT, Bayraktar et al. [8] showed that patients with HCT-CI values $\geq 2$ had significantly higher inpatient mortality than patients with values of $0-1$ and that HCT-CI values $\geq 4$ were significantly associated with shorter OS compared with values of $0-1$ (hazard ratio, 1.74; 95\% CI, 1.23-2.47). Factors associated with lower inpatient mortality were ICU admission during the conditioning phase of the transplant and use of a reduced intensity conditioning regimen. The overall inpatient mortality rate was $64 \%$, and the 1 -year OS rate was $15 \%$. Among patients with HCT-CI scores of $0-1,2,3$, and 4 , the 1 -year OS rates were $22 \%$, $17 \%, 18 \%$, and $9 \%$, respectively.

Complications of allogeneic HSCT are generally categorized as early and late effects. Early effects include primarily issues that occur within the first 100 days of the transplant. This can be further divided into three time periods: pre-engraftment, early post-engraftment, and late post-engraftment ( $>100$ days post-HSCT).

\section{Pre-engraftment Complications}

During the pre-engraftment period, most patients will start to experience side effects of the conditioning chemotherapy regimen. This includes primarily nausea, vomiting, mucositis, and diarrhea. Fever and infection are also common during this time with gram-positive bacteria, gram-negative bacteria, herpes simplex virus, respiratory viruses, enteric viruses, and fungal infections (especially Candida and Aspergillus species) being most prevalent.

\section{Early Post-engraftment Complications}

The early post-engraftment period is defined as the time of engraftment through Day +100 .
During this time, the risk for bacterial infections tends to gradually decline. However, patients tend to develop an increased risk for viral infections, immune-mediated effects of the donor cells, and noninfectious pulmonary, gastrointestinal, and liver toxicities. Patients also continue to have significant anemia and thrombocytopenia in the early post-engraftment period, which tends to persist for roughly 30-60 days posttransplant.

Immunosuppressive medications are often continued for up to 6 months posttransplant but may be continued longer in those patients who develop graft-versus-host disease. Immunosuppression during the early post-engraftment time can result in a prolonged period of increased risk for infection while awaiting reconstitution of the mature, functional lymphocyte population. It is for this reason that allogeneic HSCT patients tend to be at increased risk for atypical viral and fungal infections. There is also another peak in the risk for Aspergillus infections along with the potential for pneumocystis infection. Table 3 lists some of the common organisms and manifestations of viral infections seen in allogeneic HSCT patients.

Early noninfectious complications after allogeneic HSCT include fluid overload, acute GVHD, liver complications, pulmonary complications idiopathic pneumonia syndrome and diffuse alveolar hemorrhage - and hemorrhagic cystitis.

Fluid overload is a common complication of allogeneic HSCT. In a retrospective, single institution study of 594 patients undergoing allogeneic HSCT, Rondon et al. [59] identified a syndrome of "fluid overload" that occurred early posttransplant in the absence of other known transplant complications. This was characterized by the degree of weight gain and edema necessitating fluid removal with or without organ toxicity. The study proposed the following grading system for fluid overload: grade 1 , weight gain $<10 \%$ from baseline, asymptomatic or mild edema, possibly requiring diuretic therapy or a decrease in intravenous fluid replacement; grade 2, symptomatic fluid retention, with or without weight gain $\geq 10-<20 \%$ from baseline, requiring ongoing diuretic therapy; grade 3 , weight gain $\geq 20 \%$ from baseline, not responding to diuretic therapy, 
Table 3 Summary of viral infections in allogeneic HSCT recipients

\begin{tabular}{l}
\hline CMV \\
\hline Pneumonitis \\
\hline Esophagitis \\
\hline Colitis \\
\hline Hepatitis \\
\hline Encephalitis \\
\hline Chorioretinitis \\
\hline Varicella zoster \\
\hline Rash (shingles) \\
\hline Encephalitis \\
\hline Herpes simplex virus (HSV) \\
\hline Mucosal ulcerations from reactivation \\
\hline BK virus \\
\hline Hemorrhagic cystitis \\
\hline Nephropathy \\
\hline Adenovirus \\
\hline Pneumonitis \\
\hline Hepatitis \\
\hline Gastritis/colitis \\
\hline Cystitis \\
\hline Nephritis \\
\hline Epstein-Barr virus (EBV) \\
\hline Posttransplant lymphoproliferative disorder (PTLD) \\
\hline Human herpesvirus (HHV-6, HHV-7, HHV-8) \\
\hline Pneumonitis \\
\hline Encephalitis \\
\hline Rash \\
\hline Fever \\
\hline Marrow suppression \\
\hline Me virus \\
\hline Multifocal leukoencephalopathy \\
\hline Respiratory syncytial virus (RSV) \\
\hline Human metapneumovirus \\
\hline virus 3) \\
\hline Influenza virus \\
\hline Rhinovirus and enterovirus \\
\hline Coronavirus \\
\hline Bocavirus \\
\hline
\end{tabular}

with possible renal, pulmonary, or cardiac dysfunction requiring further treatment; and grade 4, progressive dysfunction of more than 1 organ system or requiring intensive care. The study included two cohorts. The first was a study cohort of 145 patients undergoing haploidentical HSCT with melphalan-fludarabine-based conditioning regimens. Fluid overload occurred in $66.2 \%$ of this cohort with multivariant analysis showing that grade $\geq 2$ (HR, 13.1; 95\% CI, 3.4-50; $P<0.001)$ and serum creatinine level $>1 \mathrm{mg} / \mathrm{dL}$ at transplantation admission ( $\mathrm{HR}, 3.5 ; 95 \% \mathrm{CI}$, $1.1-11 ; P=0.03)$ were significantly associated with Day +100 non-relapse mortality. This was validated in a cohort of 449 AML/MDS patients undergoing transplant from an HLA-matched related or unrelated donor following a busulfanfludarabine-based conditioning regimen.

Acute GVHD remains a significant cause of early transplant-related mortality. In the acute setting, GVHD is felt to be primarily a T-cell-driven process that is initiated by tissue damage from the conditioning regimen followed by donor T-cell activation and the associated inflammatory response. Risk factors for acute GVHD include but are not limited to increased donor-recipient HLA disparity/mismatch, increased donor age, multiparity (female donors), use of peripheral blood stem cells, and myeloablative conditioning. Acute GVHD can affect multiple organs with the most common being the skin, gastrointestinal tract, and liver. The skin is the most commonly affected organ in acute GVHD. It typically consists of a maculopapular rash that may be pruritic or even painful. Gastrointestinal (GI) tract involvement is typically categorized as upper or lower and is based upon clinical symptoms that may be supported by a tissue diagnosis or biopsy. Upper GI GVHD typically presents with nausea and anorexia, whereas lower GI tract involvement typically presents as profuse watery diarrhea with abdominal cramping. Liver involvement is less common but typically presents with a cholestatic picture [81].

Prophylaxis against acute GVHD is aimed at decreasing the expansion and activation of donor T-cells. This can be accomplished through manipulation of the graft to deplete the T-cell population or with pharmacologic agents (e.g., methotrexate, cyclosporine, and the calcineurin inhibitors tacrolimus or sirolimus). Front-line treatment of acute GVHD involves the use of high doses of corticosteroids, which may further suppress the patient's immune system, thereby increasing the risk for infection. 
Table 4 Clinical criteria for diagnosis of VOD/SOS

\begin{tabular}{l|l}
\hline Modified seattle criteria [45] & Baltimore criteria [36] \\
\hline Two or more of the following within 20 days of HSCT & Bilirubin $>2 \mathrm{mg} / \mathrm{dL}$ plus at least two of the following \\
\hline Serum total bilirubin $>2 \mathrm{mg} / \mathrm{dL}$ & Hepatomegaly \\
\hline Hepatomegaly or right upper quadrant pain & Ascites \\
\hline$>2 \%$ weight gain due to fluid retention & $>5 \%$ weight gain from pre-HSCT baseline \\
\hline
\end{tabular}

Liver disease after HSCT has multiple potential etiologies with many of the problems presenting within the first 100 days of transplant. Reactivation of viral hepatitis, fatty liver, iron overload, and acute drug toxicity are likely the most common causes of abnormal liver function tests during transplant. But the acute onset of ascites, weight gain, fluid retention, and/or rising bilirubin should prompt the concern for venoocclusive disease (VOD) or sinusoidal obstruction syndrome (SOS). VOD/SOS is thought to be the result of pre-existing damage to hepatic venous endothelial cells leading to a procoagulant state leading to deposition of fibrinogen and factor VIII within the venular walls and liver sinusoids. This leads to progressive venular occlusion followed by deposition of collagen in the sinusoids, sclerosis of venular walls, fibrosis of venular lumens, and occlusion of terminal hepatic venules and intercalated veins [22, 34, 61-65, 71]. Pre-existing liver disease combined with exposure to high-dose alkylating agents seems to pose the highest risk for the development of VOD/SOS [45]. Commonly used criteria for the diagnosis of this condition are summarized in Table 4. Doppler ultrasound of the liver and liver biopsy may be necessary to differentiate VOD/SOS from acute GVHD of the liver. One of the most promising therapies for $\mathrm{VOD} / \mathrm{SOS}$ is defibrotide, which is a polydeoxyribonucleotide adenosine receptor agonist that has been shown to affect endothelial cell function through the release of prostanoids, increase in tissue plasminogen activator (tPA), decrease levels of plasminogen activator inhibitor (PAI-1), inhibit thrombininduced platelet aggregation, and inhibit leukocyte adhesion to endothelial cells $[30,81]$. Studies of defibrotide have shown complete response rates of $30-60 \%$, including the treatment of patients with severe VOD/SOS $[11,13,16,17$, $56-58,70]$.
Table 5 Clinical spectrum idiopathic pneumonia syndrome [81]

\begin{tabular}{l}
\hline Chemoradiation toxicity \\
\hline Transfusion-related acute lung injury (TRALI) \\
\hline Diffuse alveolar hemorrhage (DAH) \\
\hline Acute respiratory distress syndrome (ARDS) \\
\hline Restrictive lung disease \\
\hline Bronchiolitis obliterans organizing pneumonia \\
(BOOP) \\
\hline Interstitial pneumonitis \\
\hline Obstructive lung disease \\
\hline Bronchiolitis obliterans \\
\hline Bronchiolitis obliterans syndrome \\
\hline Peri-engraftment respiratory distress syndrome (PERDS) \\
\hline Capillary leak syndrome
\end{tabular}

Idiopathic pneumonia syndrome is a condition is characterized by widespread alveolar injury that occurs in the absence of active lower respiratory infection and cardiac causes. It encompasses a spectrum of pulmonary disorders as seen in Table 5, with an estimated incidence of 5-20\% within the first 120 days after HSCT. Typical onset is around 3 weeks posttransplant with an estimated Day 100 mortality of $70-80 \%$. Treatment is often empiric with broad-spectrum antimicrobials and high-dose corticosteroids. Bronchoscopy with bronchoalveolar lavage (BAL) is recommended to guide therapy. If the patient has adequate platelet count, transbronchial biopsy and/or open lung biopsy may be required for more accurate diagnosis [37, 81].

Another potential respiratory complication of transplant is the development of diffuse alveolar hemorrhage (DAH). It is a rare condition but with a high mortality rate [42]. Diagnosis is suggested by the finding of patchy bilateral ground glass or consolidative opacities on imaging [39]. It is confirmed by bronchoscopy with samples that show progressively hemorrhagic returns on sequential lavages in the same subsegment of the lung. 
Samples may also show hemosiderin-laden macrophages on cytology [20]. Treatment is mostly supportive care with broad-spectrum antibiotics for cases that are suspected to be secondary to infection and glucocorticoid steroids for the treatment of underlying inflammation (i.e., capillaritis) or potential acute GVHD that is associated with some cases. The use of steroids in non-GVHD cases remains somewhat controversial since there is mixed data regarding their efficacy [9, 55]. There is also growing evidence for the potential use of recombinant factor VII as treatment for DAH [10, 29, 50, 53].

Hemorrhagic cystitis is a complication that can occur at two different time points in HSCT patients. During the pre-engraftment period, it most commonly associated with the preparative/ conditioning regimen. Treatments given during the conditioning regimen associated with hemorrhagic cystitis include high-dose cyclophosphamide, ifosfamide, busulfan, and total body irradiation. However, hemorrhagic cystitis occurring in the post-engraftment period is primarily related to BK polyomavirus infection. This typically occurs within the first 100 days posttransplant and is most likely in alternative donor transplants (e.g., unrelated donors, haploidentical, cord blood transplants) $[21,66]$. In haploidentical transplantation, the incidence of grade 2-4 hemorrhagic cystitis is approximately 25\% [54] and can be associated with obstruction and renal insufficiency [33, 38, 48]. The use of alemtuzumab as part of the conditioning regimen has also been associated with increased risk for BK virus-associated hemorrhagic cystitis [49]. Reactivation of BK virus has also been associated with delayed immunologic reconstitution [1]. Treatment includes predominantly drugs or cytotoxic T-cell lymphocytes (CTLs). Cidofovir is the predominant pharmacologic agent used to treat $\mathrm{BK}$ virus infections with an estimated overall response rate of $79 \%$ that includes about $66 \%$ of complete responses [12]. For those patients who fail to respond to pharmacologic therapy or have contraindications to such therapy, the use of CTLs is a potential option $[6,78]$. Occasionally patients will require percutaneous nephrostomy tube placement for management of ureteral stenosis or obstruction.

\section{Late Post-engraftment Complications}

The late post-engraftment period is defined as anytime beyond Day +100 . Disease progression remains the most common cause of mortality in the late post-engraftment period accounting for an estimated $47-58 \%$ of deaths over 100 days after allogeneic HSCT. However, patients may experience long-term quality of life and psychosocial issues including concerns over sexuality, fertility, financial toxicity, and integration back to society [41]. Patients also remain at risk for infection with encapsulated organisms and varicella-zoster virus while awaiting complete immune reconstitution, which may take up to 2 years in allogeneic HSCT patients [41, 75]. Much like the early postengraftment period, those patients requiring prolonged immunosuppression and corticosteroids during this time period remain at increased risk for a variety of viral and fungal infections requiring ongoing prophylaxis [75].

Another late effect of HSCT is the risk for secondary cancers. While myeloid malignancies (i.e., secondary myelodysplastic syndrome and therapy-related acute myelogenous leukemia) are most common after autologous HSCT, there is a reported incidence of solid cancers in up to $15 \%$ of patients who are recipients of autologous or allogeneic HSCT. This incidence does not seem to have a plateau and is responsible for up to $5-10 \%$ of late deaths after HSCT. Risk factors include advanced age, the use of total body irradiation, and the development of chronic GVHD. Total body irradiation seems to have a strong association with the development of adenocarcinomas, whereas chronic GVHD seems to be associated with squamous cell carcinoma of the skin. Another unique malignancy that can be seen in EBV seropositive patients after allogeneic HSCT with T-cell-depleted grafts or intensive immunosuppression is posttransplant lymphoproliferative disease (PTLD) [19].

Lastly, the development of chronic GVHD is a major cause of morbidity and reduced quality of life in long-term survivors of HSCT. Chronic GVHD and its treatment is a severely immunosuppressive condition which could be associated with various infectious complications related to 
T-cell dysfunction, like fungal or viral infections, which occasionally may need ICU care. Unlike acute GVHD, chronic GVHD tends to have a gradual onset with symptoms starting after 6 months after transplant and may evolve to organ fibrosis with involvement primarily of the skin/fascia. Classic cases of chronic GVHD tend to occur after Day 100 of transplant, but some patients can develop symptoms earlier as a progressive evolution from acute GVHD. This is known as an overlap syndrome whereby patients exhibit signs and symptoms of both acute and chronic GVHD. Approximately $70-80 \%$ of cases of chronic GVHD are preceded by acute GVHD with increased risk in patients receiving peripheral blood stem cells from unrelated donors. Treatment includes systemic therapy aimed at controlling the underlying destructive immunologic process (steroids, ruxolitinib, photopheresis) while also providing aggressive supportive care to address symptoms of pain, joint/fascia tightness, chronic dry mouth, and dry eyes. Patients also require ongoing surveillance for skin cancers. This is best accomplished in experienced transplant centers with a multidisciplinary team that includes a transplant physician, physical therapist, occupational therapist, dermatologist, and ophthalmologist as available resources [81].

\section{End of Life Issues in HSCT Patients Admitted to the ICU}

Stem cell transplant can be associated with complications that may require admission to the intensive care unit (ICU). The estimated rate of ICU admission is $3.3 \%$ for autologous HSCT [77] and approximately $16 \%$ (range of 9-30\%) for allogeneic HSCT [7, 8]. The most commonly reported reasons for ICU admission are respiratory failure, sepsis, and infection. Although, ICU admission of a stem cell transplant patient, especially with an allogeneic graft, has been associated with a poor prognosis, overall, the survival of HSCT patients requiring intensive care unit (ICU) admission has improved over the years. In fact, a single institution study of patients with hematologic malignancies admitted to the ICU showed no difference in survival between those patients who received a transplant and patients who did not receive a transplant [23]. Furthermore, a single center retrospective study of 164 allogeneic HSCT recipients admitted to the ICU showed a long-term survival rate of $61 \%$ and $51 \%$ at 1 year and 5 years, respectively. This was similar to patients who never required intensive care [76]. van Vliet et al. [79] also showed that admission to the ICU had no negative impact on long-term healthrelated quality of life for patients being treated for a hematologic malignancy. Forty-five percent $(45 \%)$ of the patients in the study were recipients of HSCT. However, one of the ongoing struggles with HSCT patients in the ICU is the ability to predict prognosis and the optimal timing for end-of-life discussions with the patients and caregivers.

Communication between the ICU and transplant teams is a key factor in avoiding conflict over the timing of admission to the ICU and goals of care. This seems to be particularly an issue for those patients who undergo allogeneic HSCT with curative intent where studies of traditional organ function indexes (i.e., APACHE II, APACHE III, and SOFA) seem to provide conflicting results for the ability to predict ICU outcomes in the HSCT population. Afessa et al. [2] found the APACHE III score to have a moderate discrimination and good calibration in predicting hospital mortality, while the APACHE II score had no prognostic value. Gilli et al. [26] concluded that the APACHE II score underestimated mortality, while the use of the SOFA score correlated with hospital mortality. Specifically, there were no patients with a SOFA score $>11$ who survived in this study. Two other studies also showed a correlation of higher SOFA score with increased hospital mortality $[47,77]$. Other studies also suggest that the need for mechanical ventilation is associated with shorter survival $[2,52,68]$. Furthermore, the combination of liver failure and renal failure in mechanically ventilated HSCT patients seems to be universally fatal $[4,25,60]$.

In addition to communication among providers, it is also imperative that the transplant team has addressed advance care planning (ACP) with the patient prior to HSCT. Ganti et al. [24] showed in a 
study of 343 patients undergoing HSCT (including both allogeneic and autologous) that ACP was associated with a decrease risk for post-HSCT mortality with an estimated 1-year probability of survival of $77 \%$ without ACP and $89 \%$ with ACP (HR for risk of death 2.11; 95\% CI, 1.34-3.33; $p=0.001$ ). This group concluded that the patients least likely to have planned for poor outcomes are the most likely to face them and engaging in ACP is not inconsistent with hoping for the best outcome in HSCT $[24,40]$.

In conclusion, the ICU care for the hematopoietic stem cell transplant patients is complex due to the severely immunosuppressed state of these patients in the early posttransplant period. Complications are primarily related to infections or organ failure from chemotherapy. Even though concerns remain with the need for ICU care in allogeneic hematopoietic transplant recipients, several studies have shown encouraging results, likely related to an overall lower intensity of conditioning regimens, better prevention of infectious complications, expanded availability of treatment options, and better recognition of potential complications that can occur in these patients.

\section{References}

1. Abudayyeh A, Hamdi A, Abdelrahim M, Lin H, Page VD, Rondon G, Andersson BS, Afrough A, Martinez CS, Tarrand JJ, Kontoyiannis DP, Marin D, Gaber AO, Oran B, Chemaly RF, Ahmed S, Abudayyeh I, Olson A, Jones R, Popat U, Champlin RE, Shpall EJ, Rezvani K. Poor immune reconstitution is associated with symptomatic BK polyomavirus viruria in allogeneic stem cell transplant recipients. Transpl Infect Dis. 2017;19(1):e12632.

2. Afessa B, Azoulay E. Critical care of the hematopoietic stem cell transplant recipient. Crit Care Clin. 2010;26:133-50.

3. Attal M, Lauwers-Cances V, Marit G, Caillot D, Moreau P, Facon T, Stoppa AM, Hulin C, Benboubker L, Garderet L, Decaux O, Leyvraz S, Vekemans MC, Voillat L, Michallet M, Pegourie B, Dumontet C, Roussel M, Leleu X, Mathiot C, Payen C, Avet-Loiseau H, Harousseau JL, I. F. M. Investigators. Lenalidomide maintenance after stem-cell transplantation for multiple myeloma. N Engl J Med. 2012;366:1782-91.

4. Bach PB, Schrag D, Nierman DM, Horak D, White P Jr, Young JW, Groeger JS. Identification of poor prognostic features among patients requiring mechanical ventilation after hematopoietic stem cell transplantation. Blood. 2001;98:3234-40.

5. Bacigalupo A, Ballen K, Rizzo D, Giralt S, Lazarus H, Ho V, Apperley J, Slavin S, Pasquini M, Sandmaier BM, Barrett J, Blaise D, Lowski R, Horowitz M. Defining the intensity of conditioning regimens: working definitions. Biol Blood Marrow Transplant. 2009; 15:1628-33.

6. Baugh KA, Tzannou I, Leen AM. Infusion of cytotoxic $\mathrm{T}$ lymphocytes for the treatment of viral infections in hematopoetic stem cell transplant patients. Curr Opin Infect Dis. 2018;31:292-300.

7. Bayraktar UD, Nates JL. Intensive care outcomes in adult hematopoietic stem cell transplantation patients. World J Clin Oncol. 2016;7:98-105.

8. Bayraktar UD, Shpall EJ, Liu P, Ciurea SO, Rondon G, de Lima M, Cardenas-Turanzas M, Price KJ, Champlin RE, Nates JL. Hematopoietic cell transplantationspecific comorbidity index predicts inpatient mortality and survival in patients who received allogeneic transplantation admitted to the intensive care unit. J Clin Oncol. 2013;31:4207-14.

9. Ben-Abraham R, Paret G, Cohen R, Szold O, Cividalli G, Toren A, Nagler A. Diffuse alveolar hemorrhage following allogeneic bone marrow transplantation in children. Chest. 2003;124:660-4.

10. Blatt J, Gold SH, Wiley JM, Monahan PE, Cooper HC, Harvey D. Off-label use of recombinant factor VIIa in patients following bone marrow transplantation. Bone Marrow Transplant. 2001;28:405-7.

11. Bulley SR, Strahm B, Doyle J, Dupuis LL. Defibrotide for the treatment of hepatic veno-occlusive disease in children. Pediatr Blood Cancer. 2007;48:700-4.

12. Cesaro S, Hirsch HH, Faraci M, Owoc-Lempach J, Beltrame A, Tendas A, Baltadakis I, Dalle JH, Koc Y, Toporski J, Styczynski J, Yesilipek MA, Heinz W, Caniglia M, Rascon J, Fauser AA, Michallet M, LopezCorral L, Neuburger S, Tridello G, Einsele H. Cidofovir for BK virus-associated hemorrhagic cystitis: a retrospective study. Clin Infect Dis. 2009;49:233-40.

13. Chopra R, Eaton JD, Grassi A, Potter M, Shaw B, Salat C, Neumeister P, Finazzi G, Iacobelli M, Bowyer K, Prentice HG, Barbui T. Defibrotide for the treatment of hepatic veno-occlusive disease: results of the European compassionate-use study. Br J Haematol. 2000;111:1122-9.

14. Congdon CC. Experimental treatment of total-body irradiation injury: a brief review. Blood. 1957;12:746-54.

15. Copelan EA. Hematopoietic stem-cell transplantation. N Engl J Med. 2006;354:1813-26.

16. Corbacioglu S, Greil J, Peters C, Wulffraat N, Laws HJ, Dilloo D, Straham B, Gross-Wieltsch U, Sykora KW, Ridolfi-Luthy A, Basu O, Gruhn B, Gungor T, Mihatsch W, Schulz AS. Defibrotide in the treatment of children with veno-occlusive disease (VOD): a retrospective multicentre study demonstrates therapeutic efficacy upon early intervention. Bone Marrow Transplant. 2004;33:189-95.

17. Corbacioglu S, Carreras E, Mohty M, Pagliuca A, Boelens JJ, Damaj G, Iacobelli M, Niederwieser D, 
Olavarria E, Suarez F, Ruutu T, Verdonck L, Hume R, Nejadnik B, Lai C, Finetto G, Richardson P. Defibrotide for the treatment of hepatic venoocclusive disease: final results from the international compassionate-use program. Biol Blood Marrow Transplant. 2016;22:1874-82.

18. D'Souza A, Fretham C. Current uses and outcomes of hematopoietic cell transplantation (HCT): CIBMTR summary slides. 2017. [Online]. Available: http:// www.cibmtr.org [Accessed].

19. Danylesko I, Shimoni A. Second malignancies after hematopoietic stem cell transplantation. Curr Treat Options Oncol. 2018;19:9.

20. de Lassence A, Fleury-Feith J, Escudier E, Beaune J, Bernaudin JF, Cordonnier C. Alveolar hemorrhage. Diagnostic criteria and results in 194 immunocompromised hosts. Am J Respir Crit Care Med. 1995;151:157-63.

21. El-Zimaity M, Saliba R, Chan K, Shahjahan M, Carrasco A, Khorshid O, Caldera H, Couriel D, Giralt S, Khouri I, Ippoliti C, Champlin R, de Lima M. Hemorrhagic cystitis after allogeneic hematopoietic stem cell transplantation: donor type matters. Blood. 2004; 103:4674-80.

22. Faioni EM, Krachmalnicoff A, Bearman SI, Federici AB, Decarli A, Gianni AM, McDonald GB, Mannucci PM. Naturally occurring anticoagulants and bone marrow transplantation: plasma protein $\mathrm{C}$ predicts the development of venocclusive disease of the liver. Blood. 1993;81:3458-62.

23. Ferra C, Marcos P, Morgades M, Misis M, Bordeje ML, Ribera JM. Similar prognosis for transplanted and non-transplanted patients with hematological malignancy admitted to the intensive care unit. Med Clin (Barc). 2008;130:573-5.

24. Ganti AK, Lee SJ, Vose JM, Devetten MP, Bociek RG, Armitage JO, Bierman PJ, Maness LJ, Reed EC, Loberiza FR Jr. Outcomes after hematopoietic stemcell transplantation for hematologic malignancies in patients with or without advance care planning. J Clin Oncol. 2007;25:5643-8.

25. Gilbert C, Vasu TS, Baram M. Use of mechanical ventilation and renal replacement therapy in critically ill hematopoietic stem cell transplant recipients. Biol Blood Marrow Transplant. 2013;19:321-4.

26. Gilli K, Remberger M, Hjelmqvist H, Ringden O, Mattsson J. Sequential Organ Failure Assessment predicts the outcome of SCT recipients admitted to intensive care unit. Bone Marrow Transplant. 2010;45:682-8.

27. Gooley TA, Chien JW, Pergam SA, Hingorani S, Sorror ML, Boeckh M, Martin PJ, Sandmaier BM, Marr KA, Appelbaum FR, Storb R, McDonald GB. Reduced mortality after allogeneic hematopoietic-cell transplantation. N Engl J Med. 2010;363:2091-101.

28. Hahn T, McCarthy PL Jr, Hassebroek A, Bredeson C, Gajewski JL, Hale GA, Isola LM, Lazarus HM, Lee SJ, Lemaistre CF, Loberiza F, Maziarz RT, Rizzo JD, Joffe S, Parsons S, Majhail NS. Significant improvement in survival after allogeneic hematopoietic cell transplantation during a period of significantly increased use, older recipient age, and use of unrelated donors. J Clin Oncol. 2013;31:2437-49.

29. Hicks K, Peng D, Gajewski JL. Treatment of diffuse alveolar hemorrhage after allogeneic bone marrow transplant with recombinant factor VIIa. Bone Marrow Transplant. 2002;30:975-8.

30. Ho VT, Revta C, Richardson PG. Hepatic venoocclusive disease after hematopoietic stem cell transplantation: update on defibrotide and other current investigational therapies. Bone Marrow Transplant. 2008;41:229-37.

31. Holstein SA, Jung SH, Richardson PG, Hofmeister CC, Hurd DD, Hassoun H, Giralt S, Stadtmauer EA, Weisdorf DJ, Vij R, Moreb JS, Callander NS, van Besien K, Gentile TG, Isola L, Maziarz RT, Bashey A, Landau H, Martin T, Qazilbash MH, Rodriguez C, McClune B, Schlossman RL, Smith SE, Hars V, Owzar K, Jiang C, Boyd M, Schultz C, Wilson M, Hari P, Pasquini MC, Horowitz MM, Shea TC, Devine SM, Linker C, Anderson KC, McCarthy PL. Updated analysis of CALGB (Alliance) 100104 assessing lenalidomide versus placebo maintenance after single autologous stem-cell transplantation for multiple myeloma: a randomised, double-blind, phase 3 trial. Lancet Haematol. 2017;4:e431-42.

32. Horan JT, Logan BR, Agovi-Johnson MA, Lazarus $\mathrm{HM}$, Bacigalupo AA, Ballen $\mathrm{KK}$, Bredeson $\mathrm{CN}$, Carabasi MH, Gupta V, Hale GA, Khoury HJ, Juckett MB, Litzow MR, Martino R, Mccarthy PL, Smith FO, Rizzo JD, Pasquini MC. Reducing the risk for transplantation-related mortality after allogeneic hematopoietic cell transplantation: how much progress has been made? J Clin Oncol. 2011;29:805-13.

33. Hwang YY, Sim J, Leung AY, Lie AK, Kwong YL. BK virus-associated bilateral ureteric stenosis after haematopoietic SCT: viral kinetics and successful treatment. Bone Marrow Transplant. 2013;48:745-6.

34. Iguchi A, Kobayashi R, Kaneda M, Kobayashi $\mathrm{K}$. Plasma protein $\mathrm{C}$ is a useful clinical marker for hepatic veno-occlusive disease (VOD) in stem cell transplantation. Pediatr Blood Cancer. 2010;54:437-43.

35. Jantunen E, Itala $M$, Lehtinen $T$, Kuittinen $O$, Koivunen E, Leppa S, Juvonen E, Koistinen P, Wiklund T, Nousiainen T, Remes K, Volin L. Early treatment-related mortality in adult autologous stem cell transplant recipients: a nation-wide survey of 1482 transplanted patients. Eur J Haematol. 2006;76:245-50.

36. Jones RJ, Lee KS, Beschorner WE, Vogel VG, Grochow LB, Braine HG, Vogelsang GB, Sensenbrenner LL, Santos GW, Saral $\mathrm{R}$. Venoocclusive disease of the liver following bone marrow transplantation. Transplantation. 1987;44:778-83.

37. Kantrow SP, Hackman RC, Boeckh M, Myerson D, Crawford SW. Idiopathic pneumonia syndrome: changing spectrum of lung injury after marrow transplantation. Transplantation. 1997;63:1079-86.

38. Khan H, Oberoi S, Mahvash A, Sharma M, Rondon G, Alousi A, Shpall EJ, Kontoyiannis DP, Champlin RE, 
Ciurea SO. Reversible ureteral obstruction due to polyomavirus infection after percutaneous nephrostomy catheter placement. Biol Blood Marrow Transplant. 2011;17:1551-5.

39. Lichtenberger JP 3rd, Digumarthy SR, Abbott GF, Shepard JA, Sharma A. Diffuse pulmonary hemorrhage: clues to the diagnosis. Curr Probl Diagn Radiol. 2014;43:128-39.

40. Loberiza FR, Ganti AK, Armitage JO, Bierman PJ, Bociek RG, Devetten MP, Maness LJ, Vose JM, Lee $\mathrm{S}$. Advance care planning (ACP) prior to hematopoietic stem cell transplantation (HSCT) in patients with cancer is associated with improved survival. J Clin Oncol. 2007;25:9026.

41. Majhail NS. Long-term complications after hematopoietic cell transplantation. Hematol Oncol Stem Cell Ther. 2017;10:220-7.

42. Majhail NS, Parks K, Defor TE, Weisdorf DJ. Diffuse alveolar hemorrhage and infection-associated alveolar hemorrhage following hematopoietic stem cell transplantation: related and high-risk clinical syndromes. Biol Blood Marrow Transplant. 2006;12:1038-46.

43. Mathe G, Thomas ED, Ferrebee JW. The restoration of marrow function after lethal irradiation in man: a review. Transplant Bull. 1959;6:407-9.

44. McCarthy PL, Owzar K, Hofmeister CC, Hurd DD, Hassoun H, Richardson PG, Giralt S, Stadtmauer EA, Weisdorf DJ, Vij R, Moreb JS, Callander NS, van Besien K, Gentile T, Isola L, Maziarz RT, Gabriel DA, Bashey A, Landau H, Martin T, Qazilbash MH, Levitan D, McClune B, Schlossman R, Hars V, Postiglione J, Jiang C, Bennett E, Barry S, Bressler L, Kelly M, Seiler M, Rosenbaum C, Hari P, Pasquini MC, Horowitz MM, Shea TC, Devine SM, Anderson $\mathrm{KC}$, Linker C. Lenalidomide after stem-cell transplantation for multiple myeloma. $\mathrm{N}$ Engl $\mathrm{J}$ Med. 2012;366:1770-81.

45. McDonald GB, Sharma P, Matthews DE, Shulman HM, Thomas ED. Venocclusive disease of the liver after bone marrow transplantation: diagnosis, incidence, and predisposing factors. Hepatology. 1984;4:116-22.

46. Myers RM, Hill BT, Shaw BE, Kim S, Millard HR, Battiwalla M, Majhail NS, Buchbinder D, Lazarus HM, Savani BN, Flowers MED, D’Souza A, Ehrhardt MJ, Langston A, Yared JA, Hayashi RJ, Daly A, Olsson RF, Inamoto Y, Malone AK, Defilipp Z, Margossian SP, Warwick AB, Jaglowski S, Beitinjaneh A, Fung H, Kasow KA, Marks DI, Reynolds J, Stockerl-Goldstein K, Wirk B, Wood WA, Hamadani M, Satwani P. Long-term outcomes among 2-year survivors of autologous hematopoietic cell transplantation for Hodgkin and diffuse large b-cell lymphoma. Cancer. 2018;124:816-25.

47. Neumann F, Lobitz O, Fenk R, Bruns I, Kostering M, Steiner S, Hennersdorf M, Kelm M, Strauer BE, Germing U, Hinke A, Haas R, Kobbe G. The sepsisrelated Organ Failure Assessment (SOFA) score is predictive for survival of patients admitted to the intensive care unit following allogeneic blood stem cell transplantation. Ann Hematol. 2008;87:299-304.
48. O’Donnell PH, Swanson K, Josephson MA, Artz AS, Parsad SD, Ramaprasad C, Pursell K, Rich E, Stock W, van Besien $\mathrm{K}$. BK virus infection is associated with hematuria and renal impairment in recipients of allogeneic hematopoetic stem cell transplants. Biol Blood Marrow Transplant. 2009;15:1038-1048 e1.

49. Park SH, Choi SM, Lee DG, Choi JH, Yoo JH, Kim SH, Kim HJ, Cho SG, Eom KS, Lee JW, Min WS, Shin WS, Kim CC. Infectious complications associated with alemtuzumab use for allogeneic hematopoietic stem cell transplantation: comparison with anti-thymocyte globulin. Transpl Infect Dis. 2009;11:413-23.

50. Pastores SM, Papadopoulos E, Voigt L, Halpern NA. Diffuse alveolar hemorrhage after allogeneic hematopoietic stem-cell transplantation: treatment with recombinant factor VIIa. Chest. 2003;124:2400-3.

51. Peggs KS, Mackinnon S. Immune reconstitution following haematopoietic stem cell transplantation. $\mathrm{Br} \mathrm{J}$ Haematol. 2004;124:407-20.

52. Pene F, Aubron C, Azoulay E, Blot F, Thiery G, Raynard B, Schlemmer B, Nitenberg G, Buzyn A, Arnaud P, Socie G, Mira JP. Outcome of critically ill allogeneic hematopoietic stem-cell transplantation recipients: a reappraisal of indications for organ failure supports. J Clin Oncol. 2006;24:643-9.

53. Pihusch M, Bacigalupo A, Szer J, von Depka Prondzinski M, Gaspar-Blaudschun B, Hyveled L, Brenner B. Recombinant activated factor VII in treatment of bleeding complications following hematopoietic stem cell transplantation. J Thromb Haemost. 2005;3:1935-44.

54. Ramlal R, Sasaki K, Cerrada SL, Srour SA, Chen J, Rondon RG, Rezvani K, Oran B, Olson A, Shpall EJ, Champlin RE, Ciurea SO. Viral reactivation in haploidentical transplants using post-transplantation cyclophosphamide - a single institution experience. Biol Blood Marrow Transplant. 2016;22:S375-6.

55. Raptis A, Mavroudis D, Suffredini A, Molldrem J, Rhee FV, Childs R, Phang S, Barrett A. High-dose corticosteroid therapy for diffuse alveolar hemorrhage in allogeneic bone marrow stem cell transplant recipients. Bone Marrow Transplant. 1999;24:879-83.

56. Richardson PG, Elias AD, Krishnan A, Wheeler C, Nath R, Hoppensteadt D, Kinchla NM, Neuberg D, Waller EK, Antin JH, Soiffer R, Vredenburgh J, Lill M, Woolfrey AE, Bearman SI, Iacobelli M, Fareed J, Guinan EC. Treatment of severe venoocclusive disease with defibrotide: compassionate use results in response without significant toxicity in a high-risk population. Blood. 1998;92:737-44.

57. Richardson PG, Murakami C, Jin Z, Warren D, Momtaz P, Hoppensteadt D, Elias AD, Antin JH, Soiffer R, Spitzer T, Avigan D, Bearman SI, Martin PL, Kurtzberg J, Vredenburgh J, Chen AR, Arai S, Vogelsang G, McDonald GB, Guinan EC. Multiinstitutional use of defibrotide in 88 patients after stem cell transplantation with severe veno-occlusive disease and multisystem organ failure: response without significant toxicity in a high-risk population and factors predictive of outcome. Blood. 2002; 100:4337-43. 
58. Richardson PG, Riches ML, Kernan NA, Brochstein JA, Mineishi S, Termuhlen AM, Arai S, Grupp SA, Guinan EC, Martin PL, Steinbach G, Krishnan A, Nemecek ER, Giralt S, Rodriguez T, Duerst R, Doyle J, Antin JH, Smith A, Lehmann L, Champlin R, Gillio A, Bajwa R, D’Agostino RB Sr, Massaro J, Warren D, Miloslavsky M, Hume RL, Iacobelli M, Nejadnik B, Hannah AL, Soiffer RJ. Phase 3 trial of defibrotide for the treatment of severe veno-occlusive disease and multi-organ failure. Blood. 2016;127:1656-65.

59. Rondon G, Saliba RM, Chen J, Ledesma C, Alousi AM, Oran B, Hosing CM, Kebriaei P, Khouri IF, Shpall EJ, Popat UR, Champlin RE, Ciurea SO. Impact of fluid overload as new toxicity category on hematopoietic stem cell transplantation outcomes. Biol Blood Marrow Transplant. 2017;23:2166-71.

60. Rubenfeld GD, Crawford SW. Withdrawing life support from mechanically ventilated recipients of bone marrow transplants: a case for evidence-based guidelines. Ann Intern Med. 1996;125:625-33.

61. Salat C, Holler E, Kolb HJ, Reinhardt B, Pihusch R, Wilmanns W, Hiller E. Plasminogen activator inhibitor-1 confirms the diagnosis of hepatic venoocclusive disease in patients with hyperbilirubinemia after bone marrow transplantation. Blood. 1997a;89:2184-8.

62. Salat C, Holler E, Wolf C, Kolb HJ, Reinhardt B, Pihusch R, Kramling HJ, Heinemann V, Haller M, Hiller E. Laboratory markers of veno-occlusive disease in the course of bone marrow and subsequent liver transplantation. Bone Marrow Transplant. 1997b;19:487-90.

63. Scrobohaci ML, Drouet L, Monem-Mansi A, Devergie A, Baudin B, D'Agay MF, Gluckman E. Liver veno-occlusive disease after bone marrow transplantation changes in coagulation parameters and endothelial markers. Thromb Res. 1991;63:509-19.

64. Shulman HM, Gown AM, Nugent DJ. Hepatic venoocclusive disease after bone marrow transplantation. Immunohistochemical identification of the material within occluded central venules. Am J Pathol. 1987;127:549-58.

65. Shulman HM, Fisher LB, Schoch HG, Henne KW, McDonald GB. Veno-occlusive disease of the liver after marrow transplantation: histological correlates of clinical signs and symptoms. Hepatology. 1994;19:1171-81.

66. Silva Lde P, Patah PA, Saliba RM, Szewczyk NA, Gilman L, Neumann J, Han XY, Tarrand J, Ribeiro R, Gulbis A, Shpall EJ, Jones R, Popat U, Walker JA, Petropoulos D, Chiattone A, Stewart J, El-Zimaity M, Anderlini P, Giralt S, Champlin RE, de Lima M. Hemorrhagic cystitis after allogeneic hematopoietic stem cell transplants is the complex result of BK virus infection, preparative regimen intensity and donor type. Haematologica. 2010;95:1183-90.

67. Sorror ML, Maris MB, Storb R, Baron F, Sandmaier BM, Maloney DG, Storer B. Hematopoietic cell transplantation (HCT)-specific comorbidity index: a new tool for risk assessment before allogeneic HCT. Blood. 2005;106:2912-9.
68. Soubani AO, Kseibi E, Bander JJ, Klein JL, Khanchandani G, Ahmed HP, Guzman JA. Outcome and prognostic factors of hematopoietic stem cell transplantation recipients admitted to a medical ICU. Chest. 2004;126:1604-11.

69. Stenehjem JS, Smeland KB, Murbraech K, Holte H, Kvaloy SO, Wethal T, Kiserud CE, Samersaw-Lund MB. Obstructive and restrictive pulmonary dysfunction in long-term lymphoma survivors after high-dose therapy with autologous stem cell transplantation. Acta Oncol. 2018;57:773-81.

70. Strouse C, Richardson P, Prentice G, Korman S, Hume R, Nejadnik B, Horowitz MM, Saber W. Defibrotide for treatment of severe veno-occlusive disease in pediatrics and adults: an exploratory analysis using data from the Center for International Blood and Marrow Transplant Research. Biol Blood Marrow Transplant. 2016;22:1306-12.

71. Tabbara IA, Ghazal CD, Ghazal HH. Early drop in protein $\mathrm{C}$ and antithrombin III is a predictor for the development of venoocclusive disease in patients undergoing hematopoietic stem cell transplantation. J Hematother. 1996;5:79-84.

72. Thomas ED, Lochte HL Jr, Lu WC, Ferrebee JW. Intravenous infusion of bone marrow in patients receiving radiation and chemotherapy. $\mathrm{N}$ Engl J Med. 1957;257:491-6.

73. Thomas ED, Lochte HL Jr, Cannon JH, Sahler OD, Ferrebee JW. Supralethal whole body irradiation and isologous marrow transplantation in man. J Clin Invest. 1959a;38:1709-16.

74. Thomas ED, Lochte HL Jr, Ferrebee JW. Irradiation of the entire body and marrow transplantation: some observations and comments. Blood. 1959b;14:1-23.

75. Tomblyn M, Chiller T, Einsele H, Gress R, Sepkowitz K, Storek J, Wingard JR, Young JA, Boeckh MJ, Center for International, B, Marrow, R, National Marrow Donor, P, European, B, Marrowtransplant, G, American Society of, B, Marrow, T, Canadian, B, Marrow Transplant, G, Infectious Diseases Society of, A, Society for Healthcare Epidemiology of, A, Association of Medical, M, Infectious Disease, C, Centers for Disease, C, Prevention. Guidelines for preventing infectious complications among hematopoietic cell transplantation recipients: a global perspective. Biol Blood Marrow Transplant. 2009;15:1143-238.

76. Townsend WM, Holroyd A, Pearce R, Mackinnon S, Naik P, Goldstone AH, Linch DC, Peggs KS, Thomson KJ, Singer M, Howell DC, Morris EC. Improved intensive care unit survival for critically ill allogeneic haematopoietic stem cell transplant recipients following reduced intensity conditioning. Br $\mathrm{J}$ Haematol. 2013;161:578-86.

77. Trinkaus MA, Lapinsky SE, Crump M, Keating A, Reece DE, Chen C, Hallett DC, Franke N, Winter A, Mikhael JR. Predictors of mortality in patients undergoing autologous hematopoietic cell transplantation admitted to the intensive care unit. Bone Marrow Transplant. 2009;43:411-5.

78. Tzannou I, Papadopoulou A, Naik S, Leung K, Martinez CA, Ramos CA, Carrum G, Sasa G, Lulla P, 
Watanabe A, Kuvalekar M, Gee AP, Wu MF, Liu H, Grilley BJ, Krance RA, Gottschalk S, Brenner MK, Rooney CM, Heslop HE, Leen AM, Omer B. Off-theshelf virus-specific $\mathrm{T}$ cells to treat $\mathrm{BK}$ virus, human herpesvirus 6, cytomegalovirus, Epstein-Barr virus, and adenovirus infections after allogeneic hematopoietic stem-cell transplantation. J Clin Oncol. 2017;35:3547-57.

79. van Vliet M, van den Boogaard M, Donnelly JP, Evers AW, Blijlevens NM, Pickkers P. Long-term health related quality of life following intensive care during treatment for haematological malignancies. PLoS One. 2014;9:e87779.

80. Weiden, et al. Antileukemic effect of graft-versus-host disease in human recipients of allogeneic-marrow grafts. NEJM. 1979;300:1068.

81. Wingard JR, Gastineau DA, Leather HL, Snyder E, Szczepiorkowski ZM. Hematopoietic stem cell transplantation: a handbook for clinicians. AABB; 2009. Bethesda, MD. 